\title{
Detection of the "Candidatus Liberibacter americanus" in Phloem Vessels of Experimentally Infected Cataranthus roseus by Scanning Electron Microscopy
}

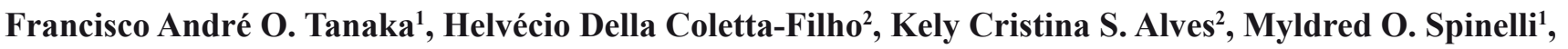 \\ Marcos Antonio Machado ${ }^{2} \&$ Elliot W. Kitajima ${ }^{1}$
}

\begin{abstract}
${ }^{1}$ Departamento de Entomologia, Fitopatologia e Zoologia Agrícola, ESALQ, Universidade de São Paulo, CEP 13418-900, Piracicaba, SP, Brazil; ${ }^{2}$ Centro APTA Citros Sylvio Moreira/IAC, Cx. Postal 0 4, CEP 13490-970, Cordeirópolis, SP, Brazil, e-mail: ewkitaji@esalq.usp.br
\end{abstract}

Author for Correspondence: Elliot W. Kitajima

\begin{abstract}
RESUMO
Detecção de Candidatus Liberibacter americanus em vasos de floema de Catharantus roseus infectados experimentalmente, utilizando microscopia eletrônica de varredura

"Candidatus Liberibacter americanus", agente causal do Huanglongbing (HLB) foi visualizado pela primeira vez ao microscópio eletrônico de varredura infectando vasos do floema de plantas de vinca (Catharantus roseus) experimentalmente infectadas utilizando-se Cuscuta sp. no Brasil.
\end{abstract}

Presence of Huanglongbing (HLB) disease in citrus orchards in the state of São Paulo has been known since 2004. Its identification was made by molecular techniques which revealed the presence of two forms of the bacteria "Candidatus Liberibacter". One previously described in Asia as Ca. L. asiaticus and the other a novel type, Ca. L. americanus (Coletta-Fo et al., Plant Dis. 88:1382. 2004; Teixeira et al., Plant Dis. 89:107. 2005). Transmission electron microscopy confirmed the presence of characteristic bacteria in the phloem vessels of affected sweet orange leaves (Tanaka et al., Fitopatol. Bras. 31:99. 2006). Attempts to observe these bacteria by scanning electron microscopy (SEM) to understand their three dimensional morphology were hindered by the extremely low concentration at which they usually occur in citrus plants. On the other hand, Ca. L. americanus was successfully transferred to the ornamental periwinkle (Cataranthus roseus (L.) G. Don.) using dodder (Cuscuta sp.) as previously reported for other Ca. Liberibacter (Garnier \& Bové, Proc. Conf. IOCV 12: 212. 1993). Infected plants developed chlorotic symptoms and contained higher concentrations of the bacterium as evaluated by molecular techniques and transmission electron microscopy. For in situ observations of Ca. L. americanus under SEM, midribs from symptomatic leaves and young stems were fixed with aldehyde, infiltrated with glycerol, immersed in liquid nitrogen and fractured with a scalpel, and the pieces post-fixed in $0.1 \% \mathrm{OsO}_{4}$ for $24 \mathrm{~h}$, dehydrated in acetone, dried at the critical point, gold coated by sputtering and examined in a LEO 435 VP scanning electron microscope. In the vascular region of the infected leaves and stems, exposed by the fracture of frozen tissues, many phloem vessels contained bacterial cells, interpreted as Ca. L. americanus, in varied numbers. Some vessels were obliterated by aggregated bacterial cells (Fig. 1 A). Bacteria were typically baciliform and elongated, 2-3 $\mu \mathrm{m}$ long with rounded ends, 200-300 nm wide and with a smooth outer surface (Fig. 1 B). These values match those obtained in sectioned bacterial cells. Such bacterial cells were absent in the phloem vessels of healthy, uninoculated periwinkle plants. This report is the first description of Candidatus Liberibacter by scanning electron microscopy.

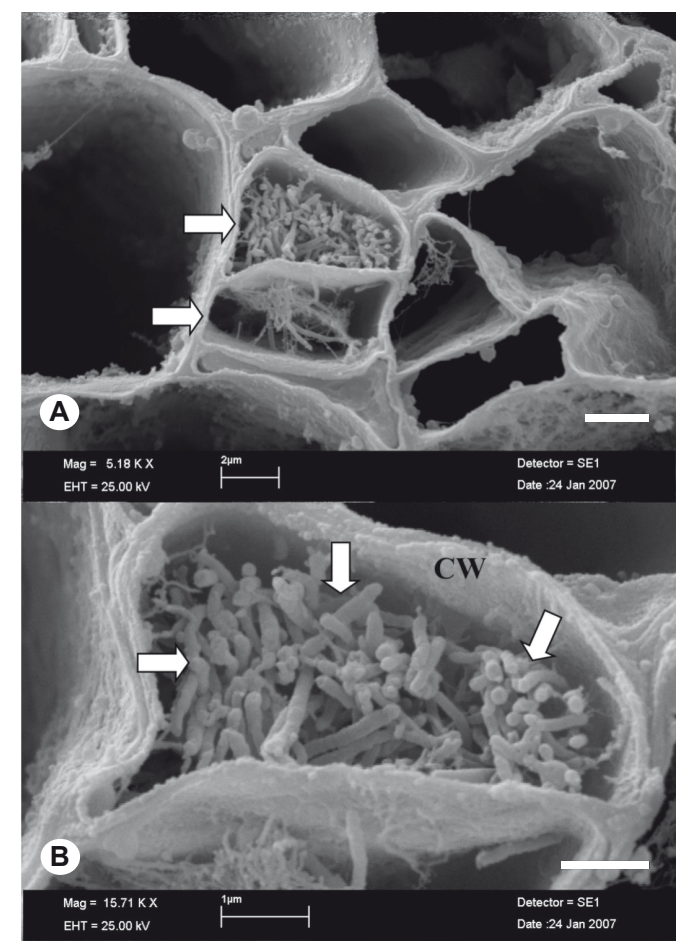

FIG. 1 - A. Scanning electron micrograph of phloem vessels (arrows) in cross section in a frozen-fractured leaf midvein of a periwinkle (Catharanthus roseus) experimentally infected by $\mathrm{Ca}$. Liberibacter americanus using dodder. One of the vessels is filled by bacilliform cells of Ca. L. americanus (bar $=2 \mu \mathrm{m}$ ). B. Detail of A, showing the bacterial cells (arrows) within the phloem element $(\mathrm{bar}=1 \mu \mathrm{m})$. 